\title{
Anti-M3 Muscarinic Acetylcholine Receptor Antibodies in Systemic Lupus Erythematosus
}

\author{
Silvia Reina',2, Cecilia Pisoni' ${ }^{3}$, Alicia Eimon ${ }^{3}$, Carolina Carrizo ${ }^{3}$, Roberto Arana ${ }^{3}$, \\ Enri Borda ${ }^{1,2 *}$ \\ ${ }^{1}$ Pharmacology Unit, School of Dentistry, University of Buenos Aires, Buenos Aires, Argentina \\ ${ }^{2}$ National Research Council of Argentina (CONICET), Buenos Aires, Argentina \\ ${ }^{3}$ Section of Rheumatology and Immunology, Department of Internal Medicine, CEMIC, Buenos Aires, Argentina \\ Email: ${ }^{*}$ enri@farmaco.odon.uba.ar
}

Received 19 December 2014; accepted 16 January 2015; published 20 January 2015

Copyright (C) 2015 by authors and Scientific Research Publishing Inc.

This work is licensed under the Creative Commons Attribution International License (CC BY). http://creativecommons.org/licenses/by/4.0/

(c) (i) Open Access

\section{Abstract}

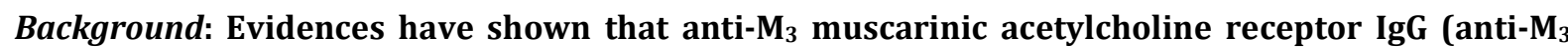
mAChR IgG) are clinically useful autoantibody that exert a cholinergic pharmacologic effect binding and interacting with $M_{3}$ mAChR at the level of exocrine gland (salivary and ocular). Aims: The aim of this study was to determine the associations between serum level of anti-M $\mathrm{M}_{3} \mathrm{mAChR}$ IgG in patients with systemic lupus erythematosus (SLE) and other autoantibodies, serum prostaglandin $\mathrm{E}_{2}\left(\mathrm{PGE}_{2}\right)$, and clinical manifestations. Methods: Serum autoantibodies against $\mathrm{M}_{3} \mathrm{mAChR}$ synthetic peptide were measured by enzyme-linked immuno absorbent assay (ELISA) using, as an antigen, a 25-mer peptide K-R-T-V-P-D-N-Q-C-F-I-Q-F-L-S-N-P-A-V-T-F-G-T-A-I corresponding to the amino acid sequence of the second extracellular loop of the human $M_{3} \mathrm{mAChR}$. Serum levels of antinuclear antibodies (ANA), anti-Smith (Sm) antibodies, anti-phospholipid (APL) antibodies, and PGE $_{2}$ were determined by ELISA in patients with SLE. Results: We found significantly enhanced titers of anti-M ${ }_{3}$ mAChR IgG in sera from SLE patients compared with healthy individuals (control). In addition, serum levels of $\mathrm{PGE}_{2}$ were significantly higher in SLE patients than in control patients and were significantly higher in active than in non-active SLE. No correlation was found with other autoantibodies present in SLE. By contrast, a positive correlation was found between anti- $\mathrm{M}_{3} \mathrm{mAChR}$

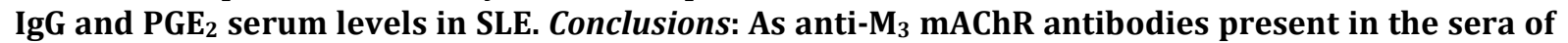
SLE patients may be another factor in the pathogenesis of this disease, and the increment of $\mathrm{PGE}_{2}$ in the sera of SLE has a modulatory action on the inflammatory process, suggesting that the presence of these autoantibodies against $M_{3} \mathbf{m A C h R}$ may contribute to sustained immune deregulation and the strong inflammatory component observed in SLE.

\footnotetext{
${ }^{*}$ Corresponding author.
} 
Keywords

Anti-M $M_{3}$ AChR Antibodies, Systemic Lupus Erythematosus, Prostaglandin $E_{2}$

\section{Introduction}

The onset and development of autoimmune disease (AID) are the consequence of interactions between genetic and environmental factors, which result in dysregulation of the immune system, and are characterized by the presence of autoantibodies and autoreactive $\mathrm{T}$ cells. Under these circumstances, immune system antimicrobial defenses react against normal components of the body and result in organ-specific or systemic immunopathology. Autoantibodies may also appear in the blood of healthy individuals or in some special situations, such as infection and the pre-clinical phase of infectious diseases [1]-[3].

Systemic lupus erythematosus (SLE) is an autoimmune disease characterized by the production of multiple autoantibodies [4]-[8], with an inflammatory/necrotic phenomenon in different tissues [9] [10]. This condition is associated with hyperactivity of B cells, and different immuno-regulatory abnormalities [11] [12]. In addition, $T$ cells from SLE patients exhibit defects in early activation events as well as an impaired proliferative response to mitogenic lectins [12] [13]. Furthermore, anti-nuclear (ANA), anti-Smith (anti-Sm), anti-phospholipid (APL), and other autoantibodies are detected in patients with SLE [4] [14] [15]. One early study, in which 23 asymptomatic pregnant women with positive anti-Ro or anti-La titers were followed for many years, reported that four subjects developed SLE, which suggested that anti-Ro or anti-La antibodies preceded the development of SLE [16]. In another study, Aho et al. reported that SLE patients were positive for ANA before the onset of SLE and the percentage was much higher than that of controls which was a much higher rate than controls [17]. Moreover, the results from the United States Department of Defense Serum Repository showed that the presence of ANA, anti-Ro, anti-La, anti-double strain deoxyribonucleic acid (anti-ds DNA), anti-Sm, APL, anti-ribonucleo protein (anti-nRNP) antibodies and rheumatoid factor (RF) preceded the onset of SLE [18]-[20]. Among SLE patients, 88\% were positive for at least one of these autoantibodies, which was a much higher percentage than healthy controls, and the prevalence of these autoantibodies increased after diagnosis [21] [22]. Anti-Ro, anti-La, and APL antibodies were the earliest detectable autoantibodies during the pre-clinical phase of rheumatoid arthritis (RA) [18]-[22]. In addition, the presence of these autoantibodies was associated with incipient severe SLE. For example, patients who were positive for anti-ds DNA antibodies often developed renal disease [22] [23], patients who were positive for IgG RF were more likely to develop arthritis [18], and positive APL was associated with malar rash and photosensitivity [19]. In addition, regular patterns exist among these autoantibodies. The majority of La-positive pre-clinical SLE patients were also Ro-positive, and a significant overlap was observed between patients positive for anti-ds DNA antibody and those positive for anti-chromatin antibody [20].

A recently published nested case-control study showed that $66 \%$ of Sjögren Syndrome (SS) patients were positive for ANA, RF, and anti-La or anti-Ro antibodies approximately 5 years before the onset of SS. A maximum of 18 years elapsed between positivity for these antibodies and the onset of SS in these subjects [23]. The seropositive rate for these antibodies and the anti- $\mathrm{M}_{3}$ muscarinic acetylcholine receptor (mAChR) autoantibodies increased as the onset of SS neared [24]-[26]. In conclusion, the evidence suggests that these autoantibodies are predictors of SS. Moreover, the presence of these autoantibodies in the serum of patients with SLE is another topic of discussion in SLE pathogenesis.

The autoimmune nature of lupus and its predominant inflammatory component was accompanied by the expression of cyclo-oxygenase-2 (COX-2) in the inflammatory areas, with the subsequent release of arachidonic acid via membrane-bound phospholipase $\mathrm{A}_{2}$. The biosynthesis of arachidonic acid by COX-2 led to an enhancement of prostanoid production of PGE2 serie, which conduct to the dysregulation in the production of proinflammatory cytokines (IL-6, IL-10, and nitric oxide) [27] [28]. Therefore, we focused on the family of prostaglandins (PG), which are the result of the oxidative modification of arachidonic acid and its cascade products through COX-2 expression and activation in patients with SLE.

\section{Aim}

The aim of our preliminary study was to investigate the inflammatory status in SLE patients compared to active and non-active groups by assessing the generation of $\mathrm{PGE}_{2}$ and its association with the presence or absence of 
anti $\mathrm{M}_{3} \mathrm{mAChR}$ autoantibodies and SLE disease activity index (SLEDAI).

\section{Methodology}

\subsection{Patients}

Blood samples from 30 patients with SLE, according to the classification criteria of the American College of Rheumatology (ACR) [29] were obtained. A total of 26 women subjects and four men subjects with a mean age of $41.4 \pm 11.9$ years were included in the study. Also, blood samples of 30 healthy women subjects with a mean age of $39.6 \pm 10.2$ years were used as controls. Fifteen patients had non-active disease $(<3)$ and 15 were considered to have active disease ( $\geq 3$ ), according to the SLEDAI measured [30] [31]. Most patients were receiving low to moderate doses of glucocorticoids as well as immunosuppressive drugs-mainly cyclophosphamide, methotrexate, azathioprine, and chloroquine. No patients with renal failure or conditions different from SLE were included in the study. The demographic and clinical characteristics of the study population (SLE patients) and normal individuals (controls) are shown in Table 1. All of the patients signed an informed consent form to participate in the study, and the investigation was conducted according to the tenets of the Declaration of Helsinki of 1975, as revised in 2000.

\subsection{Autoantibody Detection}

ELISAs were performed to measure ANA, anti-Sm, and APL using commercially available ELISA kits (INOVA Diagnostic, Inc., San Diego, CA, USA). ELISAs were performed according to the manufacturers' instructions. Values of optical density (OD) at $450 \mathrm{~nm}$ were obtained, and the IgG antibody concentrations were calculated by extrapolating $\mathrm{OD}_{450}$ values to a standard curve.

\section{3. $\mathrm{M}_{3} \mathrm{mAChR}$ Autoantibodies}

The IgG fraction from 30 patients with SLE and 30 normal subjects was independently subjected to affinity chromatography on the synthesized peptide covalently linked to AffiGel 15 gel (Bio-Rad, Richmond, CA, USA) as described previously [25]. Briefly, the IgG fraction was loaded onto the affinity column equilibrated with phosphate-buffered saline (PBS). The non-peptide fraction was first eluted with the same buffer. Specific anti-

Table 1. Demographic and clinical characteristics of SLE patients and healthy individuals.

\begin{tabular}{|c|c|c|}
\hline \multicolumn{3}{|c|}{ Clinical characteristics } \\
\hline & SLE patients & Normal individuals \\
\hline Number & 30 & 30 \\
\hline Current age, mean years \pm SD & $41.4 \pm 11.9$ & $39.6 \pm 10.2$ \\
\hline Disease duration, mean years \pm SD & $7.88 \pm 10.6$ & N/A \\
\hline Female gender, n (\%) & $26(86.7)$ & $30(100)$ \\
\hline \multicolumn{3}{|c|}{ Organ/system involved } \\
\hline Malar rash, n (\%) & $18(60.0)$ & N/A \\
\hline Photosensitivity, n (\%) & $17(56.7)$ & N/A \\
\hline Hematological, n (\%) & $23(76.6)$ & N/A \\
\hline Renal, n (\%) & $13(43.4)$ & N/A \\
\hline \multicolumn{3}{|c|}{ Current antibodies } \\
\hline ANA positive, n (\%) & $30(100)$ & N/A \\
\hline Anti-Sm positive, n (\%) & $5(16.6)$ & N/A \\
\hline Anti-phospholipid (APL) positive, n (\%) & $6(20.0)$ & N/A \\
\hline Anti-M3 synthetic peptide IgG, n (\%) & $13(43.3)$ & $3(10.0)$ \\
\hline
\end{tabular}


peptide antibodies were then eluted with $3 \mathrm{M}$ potassium thiocyanate (KSCN) and $1 \mathrm{M}$ sodium chloride (NaCl), followed by immediate extensive dialysis against PBS. The IgG concentrations of non-anti-peptide antibodies and specific anti-muscarinic receptor peptide IgG were determined by a radial immunodiffusion assay, and their immunological reactivity against muscarinic receptor peptides was evaluated by ELISA. The concentration of the affinity-purified anti-M $\mathrm{M}_{3}$ peptide $\operatorname{IgG}\left(1 \times 10^{-7} \mathrm{M}\right)$ that maximally increased optical density (OD: $\left.2.4 \pm 0.2\right)$ corresponded to a total IgG concentration of $1 \times 10^{-6} \mathrm{M}(\mathrm{OD}: 2.2 \pm 0.2)$. The normal IgG fraction purified by affinity column chromatography gave a negative result (OD: $0.24 \pm 0.03$ ).

\subsection{ELISA Assay}

Fifty microlitres of $\mathrm{M}_{3} \mathrm{mAChR}$ peptide solution in $0.1 \mathrm{M}$ sodium carbonate $\left(\mathrm{Na}_{2} \mathrm{CO}_{3}\right)$ buffer $(\mathrm{pH}=9.6)$ was used to coat microtiter plates (Corning Costar, Tewksbury, MA, USA) at $4^{\circ} \mathrm{C}$ overnight as decribed [25]. After blocking the wells, varying concentrations of purified IgG from patients with SLE and healthy individuals were allowed to react with the antigens for $2 \mathrm{~h}$ at $37^{\circ} \mathrm{C}$. The wells were then thoroughly washed with Tween ${ }^{\circledR} 20$ in PBS. Goat anti-human IgG avidin-alkaline phosphatase $(50 \mu \mathrm{l})$ was added and incubated for $1 \mathrm{~h}$ at $37^{\circ} \mathrm{C}$. After several washing steps, p-nitrophenyl phosphate $\left(1 \mathrm{mg} \cdot \mathrm{mL}^{-1}\right)$ was added as the substrate; the reaction was terminated at $30 \mathrm{~min}$. OD values were measured using an ELISA reader (Uniskan Laboratory System, Helsinki, Finland). As negative controls, non-antigen paired wells and wells with no primary antiserum were also tested.

\section{5. $\mathrm{PGE}_{2}$ Procedure}

Serum $\mathrm{PGE}_{2}$ was measured by ELISA according to the manufacturer's protocol (PGE $\mathrm{P}_{2}$ Biotrack Enzyme Immune Assay System; Amersham Bioscience, Piscataway, NJ, USA). The OD cutoff value for PGE 2 was $4.4 \pm$ $0.33 \mathrm{ng} / \mathrm{ml}$. All serum samples were frozen promptly after collection and kept at $-80^{\circ} \mathrm{C}$ until used for PGE $\mathrm{E}_{2}$ determination. The $\mathrm{PGE}_{2}$ results are expressed as $\mathrm{ng} / \mathrm{mL}$.

\subsection{Statistical Analysis}

Statistical analysis was performed using GraphPad Prism (GraphPad, San Diego, CA, USA). Statistical significance was determined by the two-tailed $t$ test for independent populations. Analysis of variance (ANOVA) and Dunn's and Kruskal-Wallis tests were employed for multiple comparisons. Pearson's analysis was applied to establish correlation. Differences between means were considered significant at $P \leq 0.05$.

\subsection{Ethical Approval of the Study Protocol}

The study was approved by the Ethics Committee of the School of Dentistry at Buenos Aires University (Buenos Aires, Argentina). The studies were conducted according to the tenets of the Declaration of Helsinki. All participants provided written informed consent to participate in the study.

\section{Results}

ELISA assays were performed to determine whether a correlation exists between serum IgG against $\mathrm{M}_{3} \mathrm{mAChR}$ synthetic peptide (Figure 1(a)) as well as serum PGE levels (Figure 1(b)) in SLE patients compared with normal individuals. Figure 1(a) shows the optical density (OD) values for each studied serum from SLE patients and normal subjects. Also, Figure 1(b) shows serum PGE 2 levels in SLE patients and normal subjects. The cut-off values obtained with SLE patient sera were always greater than two standard deviations (SD) from those from normal individuals. In Figure 1(c), a positive correlation is shown between serum PGE $_{2}$ levels and anti-M synthetic peptide titers (see table insert) of the individual sera from SLE patients.

Additionally, Table 2 shows the comparison and a statistical analysis of different autoantibodies from sera of SLE patients, showing that anti-M $\mathrm{M}_{3}$ synthetic peptide IgG was significantly different from anti-Sm antibodies and APL antibodies. No significant values were obtained when we compared anti- $\mathrm{M}_{3}$ synthetic peptide IgG with ANA.

The possible association between SLE disease activity, according to the SLEDAI and levels of anti-M $\mathrm{M}_{3}$ synthetic peptide IgG and serum PGE 2 levels (expressed as optical density values or ng/ml, respectively) was tested. Accordingly, when SLE patients were grouped on the basis of the disease status (active or non-active), no sig- 


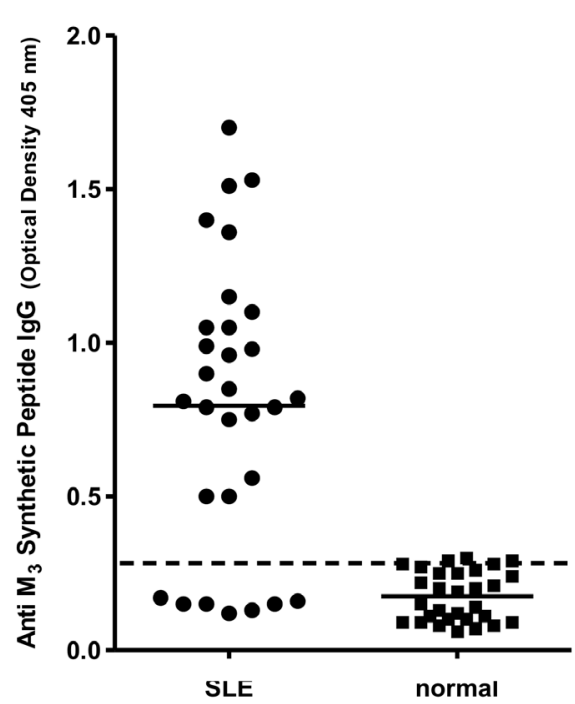

(a)

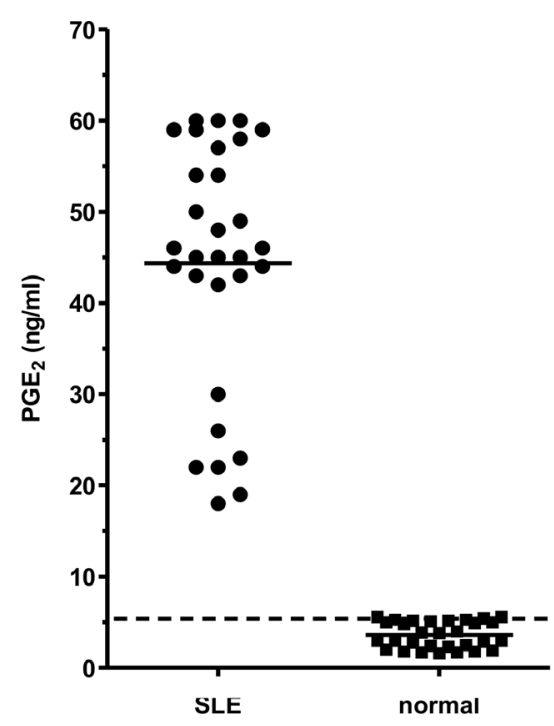

(b)

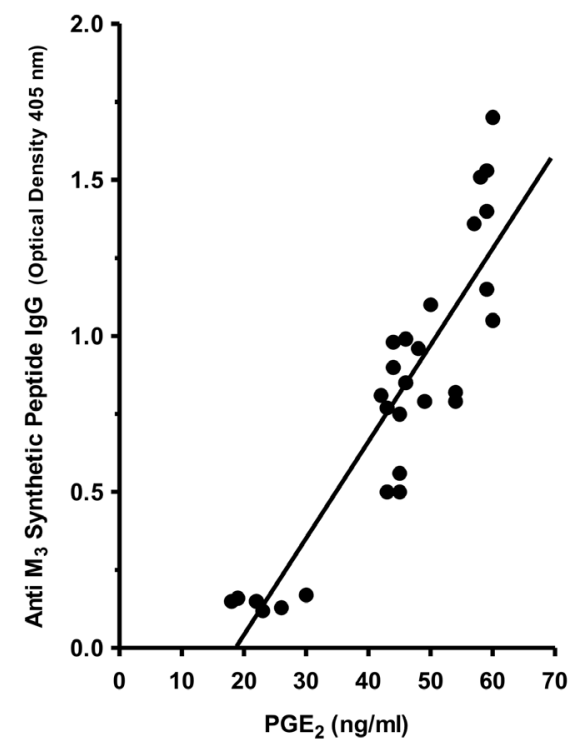

(c)

\begin{tabular}{|l|l|}
\hline Pearson $r$ & 0,9041 \\
95\% confidence interval & 0.8066 to 0.9538 \\
$\mathrm{P}$ value (two-tailed) & $\mathrm{P}<0.0001$ \\
$\mathrm{P}$ value summary & $* \star \star$ \\
Is the correlation significant? ( $\alpha=0.05)$ & Yes \\
$\mathrm{R}$ squared & 0,8175 \\
\hline
\end{tabular}

Figure 1. Scattergram showing immunoreactivity of circulating IgG antibodies against $\mathbf{M}_{3}$ mAChR synthetic peptide (a) and serum $\mathrm{PGE}_{2}$ (b). The individual optical density (OD) values for each serum sample (1:30 dilution) from 30 SLE patients and 30 normal individuals. Dotted/dashed line: cutoff values of OD 0.24 and 4.40 for anti-M $\mathrm{M}_{3} \mathrm{mAChR}$ synthetic peptide IgG and serum $\mathrm{PGE}_{2}$, respectively. Solid lines, median OD values. $P<0.0001$ between groups, and (c) correlation between the anti- $\mathrm{M}_{3}$ synthetic peptide IgG and serum PGE 2 levels.

nificant differences were found for the anti- $\mathrm{M}_{3}$ synthetic peptide IgG (Figure 2(a)). On the contrary, a significant association between active or non-active status of SLE patients was observed when we analyzed serum $\mathrm{PGE}_{2}$ levels (Figure 2(b)).

Finally, when we examined the possible association among the three parameters tested (SLEDAI, anti-M $\mathrm{M}_{3}$ synthetic peptide IgG levels, and serum PGE 2 levels) in this study, a highly significant association was found 
Table 2. Comparison between anti- $\mathrm{M}_{3}$ synthetic peptide IgG and different antibodies in SLE patients.

\begin{tabular}{ccc}
\hline Variable & Dunn's multiple comparison test & Number of patients \\
\hline Anti-M3 synthetic peptide IgG versus ANA & ns & 30 \\
Anti-M3 synthetic peptide IgG versus anti-Sm & Yes $(P<0.05)$ & 30 \\
Anti-M3 synthetic peptide IgG versus APL & Yes $(P<0.05)$ & 30 \\
\hline
\end{tabular}

Results were analyzed by one-way ANOVA followed by Kruskal-Wallis tests $(P<0.0001)$.

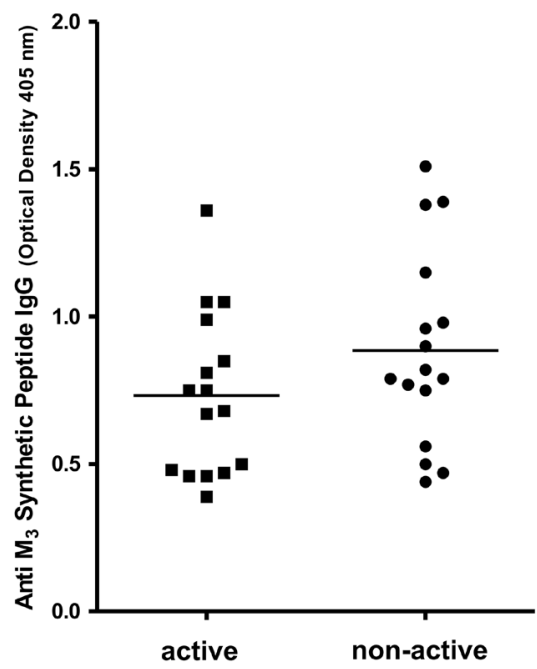

(a)

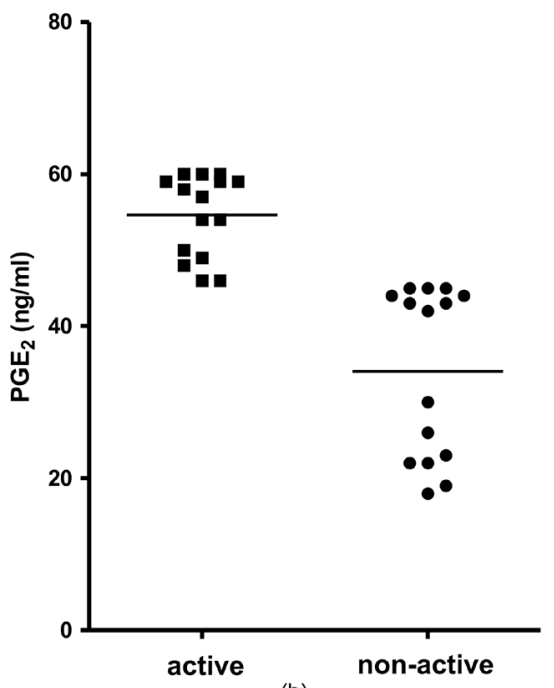

Figure 2. Scattergram showing immunoreactivity of circulating IgG antibodies against $\mathrm{M}_{3} \mathrm{mAChR}$ synthetic peptide (a) and serum $\mathrm{PGE}_{2}$ (b) in active and non-active forms of SLE disease. Values are the individual OD values for each serum sample from 30 SLE patients and 30 healthy volunteers. Dotted/dashed line: cutoff values of OD 0.24 and 4.40 for anti-M $\mathrm{M}_{3} \mathrm{mAChR}$ synthetic peptide IgG and serum $\mathrm{PGE}_{2}$, respectively. Solid lines, median OD values. $P<0.0001$ between groups.

only between the levels of $\mathrm{PGE}_{2}$ and the active and non-active SLE disease status (SLEDAI) (Table 3).

\section{Discussion}

Systemic lupus erythematosus (SLE) is a challenging disease to assess and manage. Much progress in our un- 
Table 3. Association between disease activity (SLEDAI) and levels of autoantibodies and serum PGE .

\begin{tabular}{cccc}
\hline Conditions & Active SLE & Non-active SLE & $P$ values \\
\hline SLEDAI & $6.51 \pm 0.90$ & $0.53 \pm 0.23$ & $<0.0001$ \\
Anti-M3 synthetic peptide IgG (optical density $405 \mathrm{~nm})$ & $0.73 \pm 0.10$ & $0.88 \pm 0.22$ & 0.0876 \\
PGE2 (ng/mL) & $54.60 \pm 1.39$ & $34.07 \pm 2.89$ & $<0.0001$ \\
Number of patients & 15 & 15 & N/A \\
\hline
\end{tabular}

Values represent the mean \pm SEM of 30 patients grouped according to disease activity.

derstanding of its etiopathogenesis has been made. Moreover, differences in the clinical interpretation of the signs and symptoms are attributable to the complexity of the disorder and the likely diverse mechanisms that contribute to its clinical expression. This extra challenge complicates the work of scientists who seek to understand the disease more fully and clinicians treating patients with SLE.

SLE is an autoimmune disease that not only can have very different manifestations, but may also share some pathogenic mechanisms that may help to identify therapeutic targets.

In this study, we have shown the differential expression of some autoantibodies, such as ANA, anti-Sm, and APL [18] [19], is present at a much higher percentage in sera from SLE patients than in sera from healthy individuals. In addition, we detected for the first time the presence of anti- $\mathrm{M}_{3}$ synthetic peptide IgG in the serum of SLE patients. This autoantibody was significantly associated with anti-Sm and APL antibodies but was unassociated with ANA. In previous studies was reported that ANA has the highest sensitivity in patients with SLE [32]. Moreover, the anti- $M_{3}$ synthetic peptide IgG was unassociated with malar rash, photosensitivity, or hematologic and renal alterations.

All of these autoantibodies are also associated with the clinical characteristics in the development of different clinical forms of SLE detected both in initial and chronic disease.

SLE is characterized not only by a dysregulatory immune response including overactive B-cells but is also always accompanied by an inflammatory process with $\mathrm{T}$ cell hyperactivity, where $\mathrm{PGE}_{2}$ is increased in the serum of SLE patients. That, in turn, not only modulates the immune processes at the sites of inflammation but also has the ability to generate other inflammatory cytokines [28]. However, the increased serum levels of $\mathrm{PGE}_{2}$ in SLE patients reveal that this prostanoid mediates the inflammatory process observed in this disease; under identical experimental conditions, a significant correlation between PGE $_{2}$ levels and anti- $\mathrm{M}_{3}$ synthetic peptide IgG was found.

These results appear to be a pivotal factor mediated at the level of inflammatory site, maintaining and increasing the production of other proinflammatory cytokines, such as IL-6, IL-10, and nitric oxide [33]. Therefore, $\mathrm{PGE}_{2}$ and the anti- $\mathrm{M}_{3}$ synthetic peptide antibody could be jointly responsible for the dysregulated production of proinflammatory cytokines that maintains the immune-inflammatory process characteristic of this disease.

In previous works patients with active discoid SLE were shown to have a strong expression of COX-2 in the inflammatory areas [27].

When SLE patients were grouped on the basis of disease activity (active and non-active disease), no significant differences were found for anti- $\mathrm{M}_{3}$ synthetic peptide IgG titers, though a significant difference in serum $\mathrm{PGE}_{2}$ levels was observed. Perhaps the increase in $\mathrm{PGE}_{2}$ is necessary to maintain the active inflammatory process in the course of SLE disease.

Although a possible association exists between the presence of elevated levels of anti- $\mathrm{M}_{3}$ synthetic peptide IgG and many different clinical and laboratory parameters, we failed to find a significant correlation with most of these parameters. However, a significant correlation between the titer of this cholinergic autoantibody and the production of $\mathrm{PGE}_{2}$ was detected. These data suggest that, first, the anti- $\mathrm{M}_{3}$ synthetic peptide IgG may participate in the onset of the disease, and second, these autoantibodies may contribute to the generation of other proinflammatory cytokines.

\section{Conclusion}

On the basis of our results, we have demonstrated significantly enhanced titers of anti- $\mathrm{M}_{3}$ synthetic peptide IgG 
in patients with SLE, as well as significantly higher levels of serum $\mathrm{PGE}_{2}$. We consider that $\mathrm{PGE}_{2}$ and these cholinergic autoantibodies may contribute, in part, to the pathogenesis of the autoreactive and inflammatory phenomenon described here and observed in SLE patients.

\section{Acknowledgements}

This study was supported by grants from the University of Buenos Aires (UBACyT 2011-2014) and CONICET (PIP 2014).

\section{Conflict of Interest}

The authors declare that they have no vested interest that could be constructed to have inappropriately influenced this study.

\section{References}

[1] Deane, K.D. (2014) Preclinical Rheumatoid Arthritis (Autoantibodies): An Updated Review. Current Rheumatology Report, 16, 419-422. http://dx.doi.org/10.1007/s11926-014-0419-6

[2] Bizzaro, N. (2007) Autoantibodies as Predictors of Disease: The Clinical and Experimental Evidence. Autoimmunity Review, 6, 325-333. http://dx.doi.org/10.1016/j.autrev.2007.01.006

[3] Bizzaro, N. (2008) The Predictive Significance of Autoantibodies in Organ-Specific Autoimmune Diseases. Clinical Reviews in Allergy \& Immunology, 34, 326-331. http://dx.doi.org/10.1007/s12016-007-8059-5

[4] Sherer, Y., Gorstein, A., Fritzler, M.J. and Shoenfeld, Y. (2004) Autoantibody Explosion in Systemic Lupus Erythematosus: More than 100 Different Antibodies Found in SLE Patients. Seminars in Arthritis and Rheumatism, 34, 501537. http://dx.doi.org/10.1016/j.semarthrit.2004.07.002

[5] Li, Q.Z., Zhou, J., Wandstrat, A.E., Carr-Johnson, F., Branch, V. and Karp, D.R. (2007) Protein Array Autoantibody Profiles for Insights into Systemic Lupus Erythematosus and Incomplete Lupus Syndromes. Clinical Experimental Immunology, 147, 60-70.

[6] Mansour, R.B., Lassoued, S., Gargouri, B., El Gaid, A., Attia, H. and Fakhfakh, F. (2008) Increased Levels of Autoantibodies against Catalase and Superoxide Dismutase Associated with Oxidative Stress in Patients with Rheumatoid Arthritis and Systemic Lupus Erythematosus. Scandinavian Journal of Rheumatology, 37, 103-108. http://dx.doi.org/10.1080/03009740701772465

[7] Magalhaes, M.B., da Silva, L.M., Voltarelli, J.C., Donadi, E.A. and Louzada-Junior, P. (2007) Lymphocytotoxic Antibodies in Systemic Lupus Erythematosus Are Associated with Disease Activity Irrespective of the Presence of Neuropsychiatric Manifestations. Scandinavian Journal of Rheumatology, 6, 442-447. http://dx.doi.org/10.1080/03009740701482768

[8] Braun, A., Sis, J., Max, R., Mueller, K., Fiehn, C., Zeier, M. and Andrassy, K. (2007) Anti-Chromatin and Anti-C1q Antibodies in Systemic Lupus Erythematosus Compared to Other Systemic Autoimmune Diseases. Scandinavian Journal of Rheumatology, 36, 291-298. http://dx.doi.org/10.1080/03009740701218717

[9] D’Cruz, D.P., Khamashta, M.A. and Hughes, G.R. (2007) Systemic Lupus Erythematosus. Lancet, 369, 587-596. http://dx.doi.org/10.1016/S0140-6736(07)60279-7

[10] Rahman, A. and Isenberg, D.A. (2008) Systemic Lupus Erythematosus. New England Journal of Medicine, 358, 929939. http://dx.doi.org/10.1056/NEJMra071297

[11] Pugh-Bernard, A.E. and Cambier, J.C. (2006) B Cell Receptor Signaling in Human Systemic Lupus Erythematosus. Current Opinion in Rheumatology, 18, 451-455. http://dx.doi.org/10.1097/01.bor.0000240353.99808.5f

[12] Nagy, G., Koncz, A. and Perl, A. (2005) T- and B-Cell Abnormalities in Systemic Lupus Erythematosus. Critical Reviews in Immunology, 25, 123-140. http://dx.doi.org/10.1615/CritRevImmunol.v25.i2.30

[13] Ishikawa, S., Akakura, S., Abe, M., Terashima, K., Chijiiwa, K., Nishimura, H., Hirose, S. and Shirai, T. (1998) A Subset of CD4 ${ }^{+}$T Cells Expressing Early Activation Antigen CD69 in Murine Lupus: Possible Abnormal Regulatory Role for Cytokine Imbalance. Journal of Immunology, 161, 1267-1273.

[14] Bohm, I. (2004) Apoptosis: The Link between Autoantibodies and Leuko-/Lymphocytopenia in Patients with Lupus Erythematosus. Scandinavian Journal of Rheumatology, 33, 409-416. http://dx.doi.org/10.1080/03009740410006907

[15] Reichlin, M. (1993) Antibodies to Defined Antigens in the Systemic Rheumatic Diseases. Bulletin on the Rheumatic Diseases, 42, 4-6.

[16] Waltuck, J. and Buyon, J.P. (1994) Autoantibody-Associated Congenital Heart Block: Outcome in Mothers and Child- 
ren. Annals of Internal Medicine, 120, 544-551. http://dx.doi.org/10.7326/0003-4819-120-7-199404010-00003

[17] Aho, K., Koskela, P., Makitalo, R., Heliovaara, M. and Palosuo, T. (1992) Antinuclear Antibodies Heralding the Onset of Systemic Lupus Erythematosus. Journal of Rheumatology, 19, 1377-1379.

[18] Heinlen, L.D., McClain, M.T., Merrill, J., Akbarali, Y.W., Edgerton, C.C., Harley, J.B. and James, J.A. (2007) Clinical Criteria for Systemic Lupus Erythematosus Precede Diagnosis, and Associated Autoantibodies Are Present before Clinical Symptoms. Arthritis \& Rheumatism, 56, 2344-2351. http://dx.doi.org/10.1002/art.22665

[19] McClain, M.T., Arbuckle, M.R., Heinlen, L.D., Dennis, G.J., Roebuck, J., Rubertone, M.V., Harley, J.B. and James, J.A. (2004) The Prevalence, Onset, and Clinical Significance of Antiphospholipid Antibodies Prior to Diagnosis of Systemic Lupus Erythematosus. Arthritis \& Rheumatism, 50, 1226-1232. http://dx.doi.org/10.1002/art.20120

[20] Heinlen, L.D., McClain, M.T., Ritterhouse, L.L., Bruner, B.F., Edgerton, C.C., Keith, M.P., James, J.A. and Harley, J.B. (2010) 60 kD Ro and nRNP A Frequently Initiate Human Lupus Autoimmunity. PLoS ONE, 5, e9599. http://dx.doi.org/10.1371/journal.pone.0009599

[21] Arbuckle, M.R., McClain, M.T., Rubertone, M.V., Scofield, R.H., Dennis, G.J., James, J.A. and Harley, J.B. (2003) Development of Autoantibodies before the Clinical Onset of Systemic Lupus Erythematosus. New England Journal of Medicine, 349, 1526-1533. http://dx.doi.org/10.1056/NEJMoa021933

[22] Arbuckle, M.R., James, J.A., Kohlhase, K.F., Rubertone, M.V., Dennis, G.J. and Harley, J.B. (2001) Development of Anti-dsDNA Autoantibodies Prior to Clinical Diagnosis of Systemic Lupus Erythematosus. Scandinavian Journal of Immunology, 54, 211-219. http://dx.doi.org/10.1046/j.1365-3083.2001.00959.X

[23] Jonsson, R., Theander, E., Sjöström, B., Brokstad, K. and Henriksson, G. (2013) Autoantibodies Present before Symptom Onset in Primary Sjögren Syndrome. JAMA, 310, 1854-1855. http://dx.doi.org/10.1001/jama.2013.278448

[24] Tzioufas, A.G., Kapsogeorgou, E.K. and Moutsopoulos, H.M. (2012) Pathogenesis of Sjögren’s Syndrome: What We Know and What We Should Learn. Journal of Autoimmunity, 39, 4-8. http://dx.doi.org/10.1016/j.jaut.2012.01.002

[25] Reina, S., Sterin-Borda, L., Orman, B. and Borda, E. (2004) Autoantibodies against Cerebral Muscarinic Cholinoceptors in Sjögren Syndrome: Functional and Pathological Implications. Journal of Neuroimmunology, 150, 107-115. http://dx.doi.org/10.1016/i.jneuroim.2004.01.019

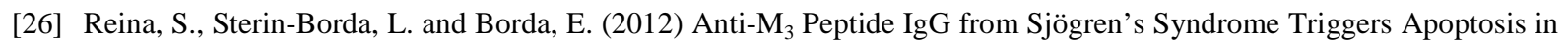
A253 Cells. Cellular Immunology, 275, 33-41. http://dx.doi.org/10.1016/j.cellimm.2012.03.006

[27] Chae, B.S., Shin, T.Y., Kim, D.K., Eun, J.S., Leem, J.Y. and Yang, J.H. (2008) Prostaglandin E E-Mediated Dysregulation of Proinflammatory Cytokine Production in Pristane-Induced Lupus Mice. Archives of Pharmacal Research, 31, 503-510. http://dx.doi.org/10.1007/s12272-001-1185-6

[28] Abreu-Velez, A.M., Smith Jr., G. and Howard, M.S. (2011) Activation of the Signaling Cascade in Response to T Lymphocyte Receptor Stimulation and Prostanoids in a Case of Cutaneous Lupus. North American Journal of Medical Sciences, 3, 251-254. http://dx.doi.org/10.4297/najms.2011.3251

[29] Tan, E.M., Cohen, A.S., Fries, J.F., Masi, A.T., McShane, D.J., Rothfield, N.F., Schaller, J.G., Talal, N. and Winchester, R.J. (1982) The 1982 Revised Criteria for the Classification of Systemic Lupus Erythematosus. Arthritis \& Rheumatism, 25, 1271-1277. http://dx.doi.org/10.1002/art.1780251101

[30] Bombardier, C., Gladman, D.D., Urowitz, M.B., Caron, D., Chang, C.H., et al., The Committee on Prognosis Studies in SLE (1992) Derivation of the Sledai. A Disease Activity Index for Lupus Patients. Arthritis \& Rheumatism, 35, 630640. http://dx.doi.org/10.1002/art.1780350606

[31] Guzman, J., Cardiel, M.H., Arce-Salinas, A., Sánchez-Guerrero, J. and Alarcón-Segovia, D. (1992) Measurement of Disease Activity in Systemic Lupus Erythematosus. Prospective Validation of 3 Clinical Indices. Journal of Rheumatology, 19, 1551-1558.

[32] Eriksson, C., Kokkonen, H., Johansson, M., Hallmans, G., Wadell, G. and Rantapaa-Dahlqvist, S. (2011) Autoantibodies Predate the Onset of Systemic Lupus Erythematosus in Northern Sweden. Arthritis Research \& Therapy, 13, R30R34. http://dx.doi.org/10.1186/ar3258

[33] Tsai, C.Y., Wu, T.H., Tsai, S.T., Chen, K.H., Thajeb, P., Lin, W.M., Yu, H.S. and Yu, C.L. (1994) Cerebrospinal Fluid Interleukin-6, Prostaglandin $E_{2}$, and Autoantibodies in Patients with Neuropsychiatric Systemic Lupus Erythematosus and Central Nervous System Infections. Scandinavian Journal of Rheumatology, 23, 57-63. http://dx.doi.org/10.3109/03009749409103028 
Scientific Research Publishing (SCIRP) is one of the largest Open Access journal publishers. It is currently publishing more than 200 open access, online, peer-reviewed journals covering a wide range of academic disciplines. SCIRP serves the worldwide academic communities and contributes to the progress and application of science with its publication.

Other selected journals from SCIRP are listed as below. Submit your manuscript to us via either submit@scirp.org or Online Submission Portal.
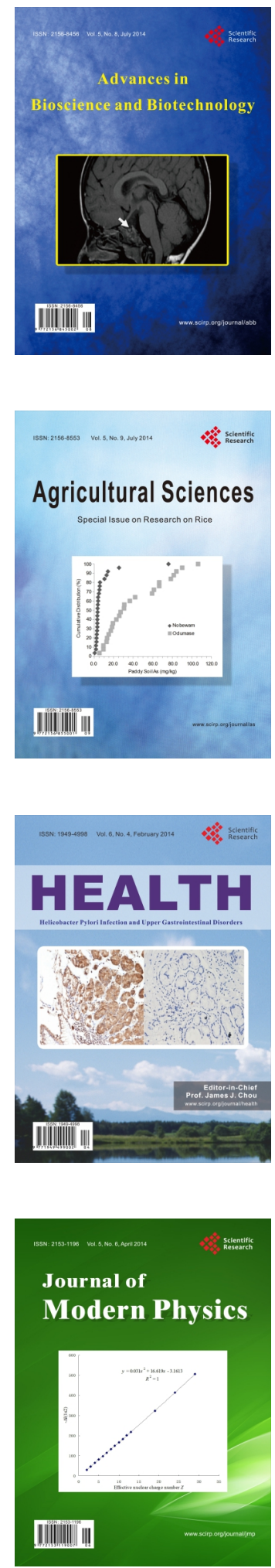
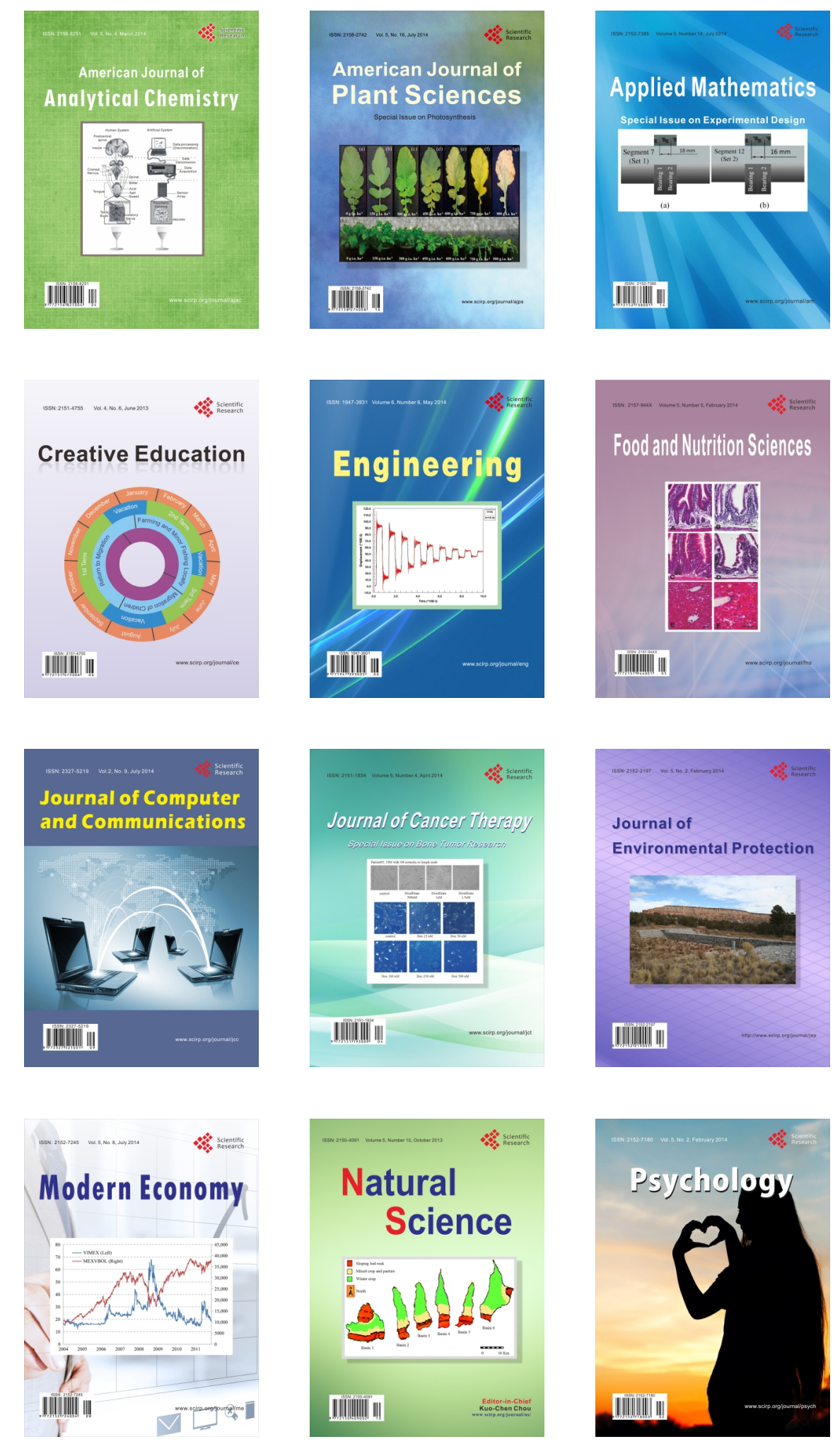